\title{
A Case of Bilateral Chylothorax Following Left Neck Dissection
}

\author{
Akiyuki Yamato, Kenji Hattori and Kayoko Shingai
}

\begin{abstract}
We experienced a case of bilateral chylothorax following left neck dissection. The patient was a 70year-old woman. For cancer of the left side of tongue base, the tongue was totally resected and reconstructed with a pectoralis major muscle flap. At the same time, a left modified radical neck dissection was performed. We found intraoperative chyle leakage, so we ligated the thoracic duct and covered it with muscle. The next day, the patient complained of dyspnea, and chylothorax was observed at both sides. Conservative treatment, such as thoracostomy tube placement, perenteral nutrition, and percutaneous administration of octreotide improved the chylothorax. Tissues around the thoracic duct should be carefully handled during neck dissection. When post-operative respiratory discomfort is found, chylothorax must also be carefully taken into consideration.
\end{abstract}

Keywords : chylothorax, neck dissection, octreotide

\section{References}

1) Light RW : Pleural effusions. Med Clin North Am 95: 10551070, 2011.

2) Mitani K, Yoshida J, Akahani S, et al. : A case of bilateral chylothorax following left neck dissection. Pract Otol (Kyoto) 92: 1241-1245, 1999.

3）村松泰徳, 長谷川泰久, 松浦秀博, 他 : 頸部郭清術後の乳 糜漏と乳糜胸。 日口腔外会誌 39: 583-586, 1993.

4) Davis HK : A statistical study of the thoracic duct in man. Am J Anat 17: 211-244, 1915.

5）久保隆一，調 賢哉：頸部郭清術における胸管損傷の問題. 耳鼻と臨 9: 1-13, 1963.
6）西井竜彦, 村松 高, 古市基彦, 他 : オクトレオチドが有 効であった術後乳糜胸の一例. 日呼外会誌 25: 635-638, 2011.

7）吉岡伸高, 伊東信久, 加茂理英, 他：OK-432 による硬化療 法を行った頸部郭清術後乳糜胸の 1 例. 形成外科 41:831836, 1998.

8) Selle JG, Snyder WH 3rd and Schreiber JT : Chylothorax: indications for surgery. Ann Surg 177: 245-249, 1973.

9）黑須正夫：胸管の局所解剖. 日気管食道会報 14：25-28, 1963.

10）門田伸也：胸管からのリンパ漏が止まらない. 耳鼻・頭頸 外科 83: 473-477, 2011.
Department of Otolaryngology, Head and Neck Surgery, Sumitomo Hospital
Corresponding Author Address : Akiyuki Yamato

yamato-akiyuki@sumitomo-hp.or.jp 


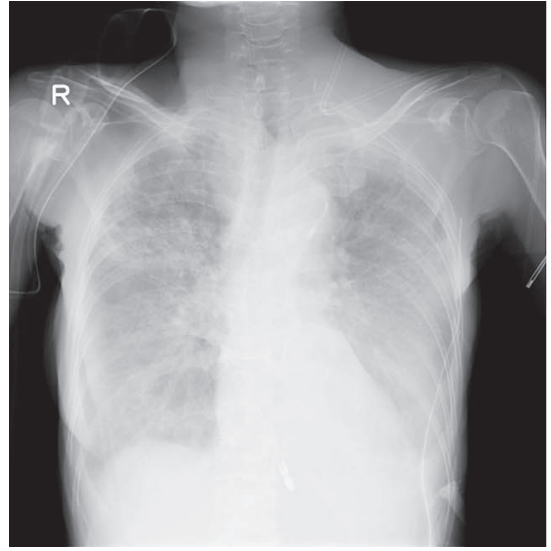

\section{A}

A: Findings of the chest X-ray at the second day after surgery The permeability of the bilateral lung fields has decreased. B: CT scan of the lung

Pleural effusions can be seen in the bilateral chest cavities.

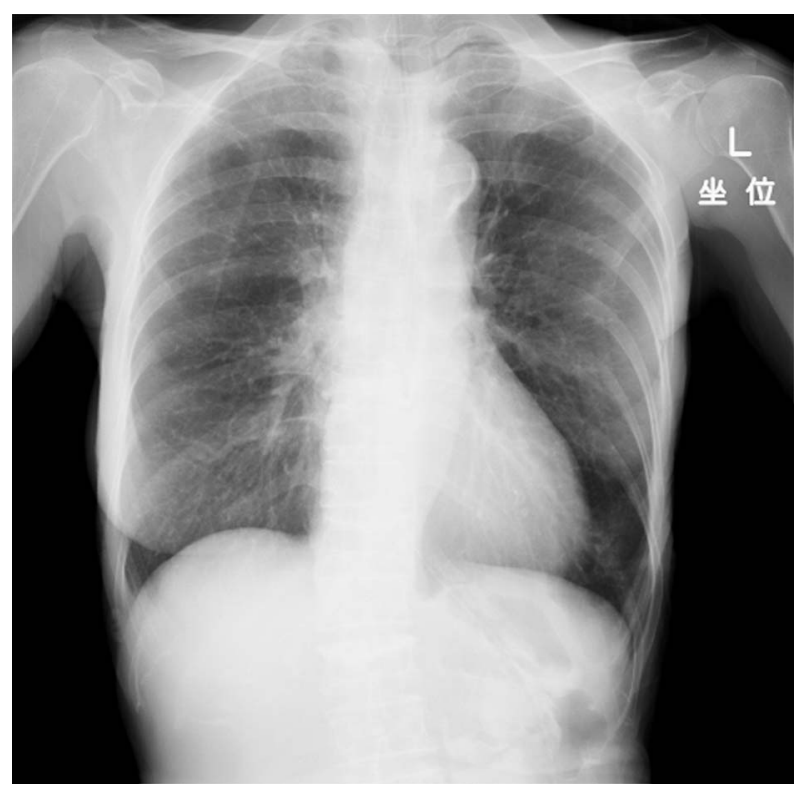

Chest X-ray findings after the treatment The lung field permeability has improved.

\section{B}

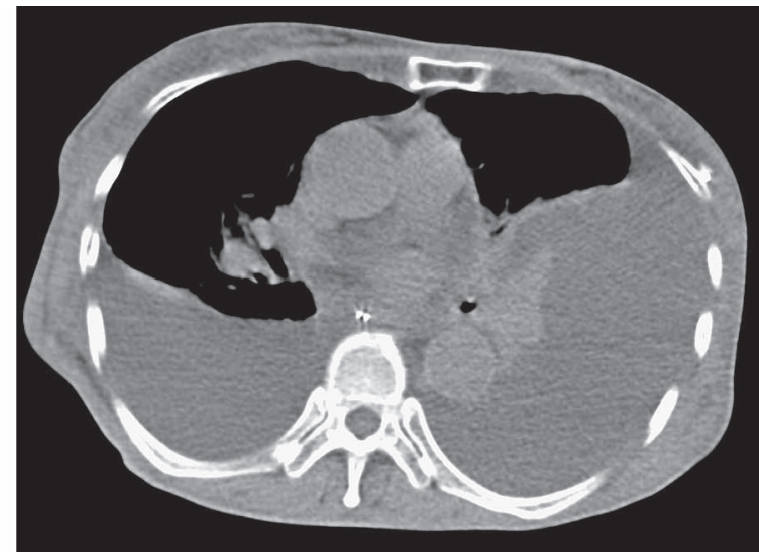

